\title{
Biomass Stove Design Based Quality Function Deployment (QFD) and Design for Manufacture and Assembly (DFMA)
}

\author{
Yohanes, ${ }^{\mathrm{a},}$, and Muhammad Idris, ${ }^{\mathrm{b}}$ \\ a) Laboratory Technology Production, Mechanical Engineering Department, Universitas Riau, Indonesia \\ b) Mechanical Engineering Students, Universitas Riau, Indonesia
}

*Corresponding author: yohanes@lecturer.unri.ac.id

\section{Paper History}

Received: 20-August-2021

Received in revised form: 19-October-2021

Accepted: 30-November-2021

\begin{abstract}
This study aims to design a biomass stove as a solution for lack of LPG gas in the community in Batu Panjang, Rupat Island, Riau. The Quality Function Deployment (QFD) method is used in this study by elaborating consumer needs through public opinion needs (questionnaire survey) and elaboration of the characteristics of consumer needs. A House of Quality (HoQ) matrix was created to determine the technical characteristics for design analysis of biomass stove and designed using the Design for Manufacture and Assembly (DFMA). The result was a development of "Biomass Stove", which consists of a funnel for fuel, a fire funnel, a filter and an air chamber. The funnel chamber, which the fuel was made the insulation channel and the joining of the fire connector forms an angle to increase the heat flow to funnel fuel and reduce the heat loss during cooking. The stove design is made safe, comfortable for users and environmentally friendly due to the existence of a filter and air chamber cover. The biomass stove was designed portable, then it was light and easy to move around.
\end{abstract}

KEY WORDS: Quality Function Deployment (QFD), House of Quality, Design for Manufacture and Assembly (DFMA), Biomass Stove.

\subsection{INTRODUCTION}

The biomass is organic material that can be sourced from forest products, household wastes, agricultural and livestock products and residues. The biomass has chemical energy that comes from the photosynthesis process by plants. Although biomass is not the main energy source for the industrial and transportation sectors, it supplies $15-20 \%$ of the world's total energy needs [1].
In theory, Indonesia's biomass energy potential is estimated at around 49,810 MW [2]. This figure is assumed on the basis of the energy content of an annual production of approximately 200 million tones of biomass from agricultural, forestry, plantation and municipal solid waste residues. The large amount of potential is not proportional to the installed capacity of $302.4 \mathrm{MW}$ or 0.64 percent utilized [3]. If we maximize the existing potential by increasing the installed capacity, it will help fossil fuels which have been the foundation of energy use [3].

The development of renewable energy sources, including biomass, is fundamental to the sustainability of future energy availability [2]. Biomass can play an important role as a renewable energy source, which serves as a provider of carbon sources for energy, which by using modern technology in its conversion can keep emissions at low levels. In addition, the use of biomass energy can also accelerate the rehabilitation of degraded lands and the protection of water systems. In general, the diversity of biomass sources and their renewable nature can act as an energy security in the future as well as play a role in biodiversity conservation [4-5].

Energy needs in remote areas related to the conversion of the root material from kerosene to gas are very influential. Departing from the difficulty of gas fuel was experiencing scarcity in the Batu Panjang, Rupat village. Then, dependence on gas was very necessary in the daily life of the Batu Panjang village community. The solution arises to overcome the problem of gas scarcity, namely utilizing the existing biomass potential around the Batu Panjang village. From the potential of the biomass in the area, it can be used as fuel for the biomass stove, which will be used as a solution to the gas scarcity.

Potential biomass such as firewood is usually used by the community in the stove as a tool for cooking. The efficiency of the stove is not good as it has a lot of smoke and therefore changes are needed to the stove. Then a solution arises as an alternative technology for the household scale, namely the biomass stove. Therefore, it is needed the design of a stove that is affordable, easy to carry, and easy to operate.

This study aims to develop a biomass stove design based Quality Function Deployment (QFD) and Design for Manufacture and Assembly (DFMA). A case study was done in the community in Batu Panjang, Rupat Island, Riau, Indonesia. 


\subsection{FUNDAMENTAL THEORY}

\subsection{Stoves and Furnaces}

The stove is a cooking utensil that produces high heat. Usually stoves are found in the kitchen and the fuel can be divided into three types, namely liquid, solid, and gas. Basically, the types of stoves that are widely used by the community are kerosene stoves and gas stoves. However, there are other types that can also be used as cooking tools, one of a biomass briquette stove or coal briquette stove. Moreover, the current condition where the price of fuel for oil and gas stoves is getting more expensive, it is necessary to pay attention to the various types of stoves with alternative fuels without oil and gas, so it can be used by the community if the oil stove and gas stove, which no longer be used [6].

The furnace is a place room that can be heated with fuel or electricity and used to burn raw materials to be processed. The use of a kiln is to burn the raw objects that are arranged in it and burn using a special fuel (wood, stone, oil, gas, or electricity) until all the heat is spread out and burns everything on the stove. Furnace can also be referred to as a tool that is made or designed as a place to heat something. The furnace itself can be made in such a way. A simple furnace made of bricks can be adjusted, so that the heat or heat does not harm the user [7].

\subsection{Quality Function Deployment (QFD)}

The Quality Function Deployment is a structured process or mechanism for determining customer needs and translating those requirements into relevant technical requirements, which each functional area and organizational level can understand and act on [8-9]. The implementation of Quality Function Deployment basically consists of three stages, where all activities at each stage can be applied as in a project by carrying out the planning stage first [9]. The three stages that are passed are [10]:

1) Voice of Customer Collection

The collection of voice of customers is done by means of a survey is written as an attribute of the product or service.

These attributes are usually referred to as qualitative customer data and the numerical information of each attribute as quantitative data. Qualitative data are generally obtained from discussions and direct observation with consumers, while quantitative data is obtained from surveys or voting.

2) Compilation of House of Quality

The application of the Quality Function Deployment method in the product or service design process begins with the formation of a product planning matrix or often referred to as the House of Quality.

3) Analysis and Implementation

This stage is the process of entering the data that has been obtained into the House of Quality, which is then analyzed. The four stages in the Quality Function Deployment system are

- The product planning stage, also known as the House of Quality.

- Planning stages.

- Stages of process planning and production.

- Operation planning stages.

\subsection{House Of Quality (HOQ)}

The process in QFD is carried out by compiling one or more matrices called The House Of Quality. This matrix explains what the customer needs and expectations are and how to fulfill them.

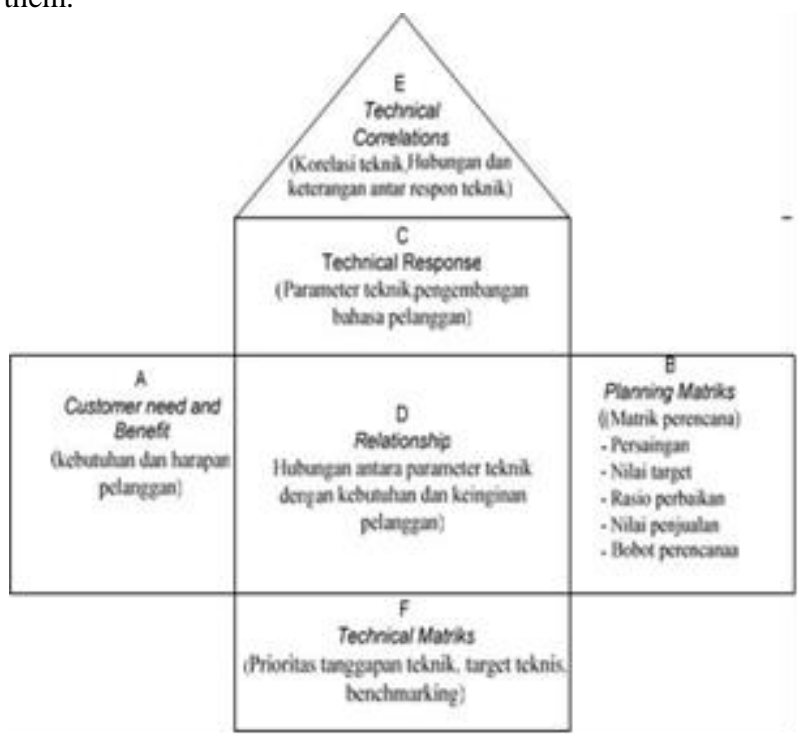

Figure 1: The House of Quality (HoQ) [10]

\subsection{Design for Manufacture and Assembly (DFMA)}

DFMA (Design for Manufacture and Assembly) consists of design for manufacture (DFM) and design for assembly (DFA) DFM aims to simplify the manufacturing process of each component making up the product and DFA aims to simplify the product structure, so that the assembly process to be shorter [11-12].

The DFMA is used for three main activities, there are [12]:

1. As the basis for concurrent engineering studies to provide guidance to the design team in simplifying the product structure, to reduce manufacturing and assembly costs, and to quantify the improvements.

2. As a benchmarking tool to study competitors' products and quantify manufacturing and assembly difficulties.

3. As a should-cost tool to help negotiate suppliers contracts. The DFMA flowchart can be seen in Figure 2.

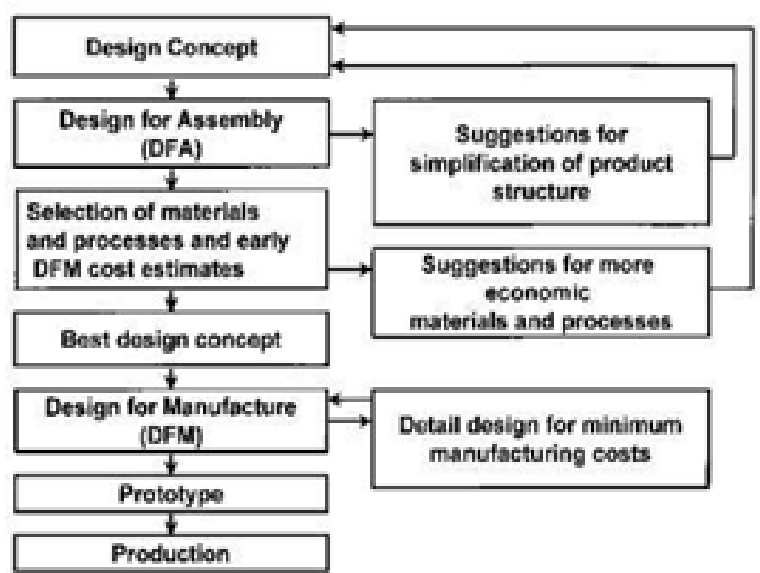

Figure 2: The DFMA process diagram [12]

Stages are made when using DFMA during design. The DFA analysis is first conducted leading to a simplification of the product structure. Then, using DFM, early cost estimates for the parts are obtained for both the original design and the new design in order to make trade-off decisions. During this 
process the best materials and processes to be used for the various parts are considered. Once the final selection of materials and processes has occurred, a more thorough analysis for DFM can be carried out for the detail design of parts [12].

\subsection{METHOD}

\subsection{Research Method}

The research method provides an overview of the research design, which includes procedures and steps to be taken, research time, data sources, and problem solving method. The flow chart of the research carried out can be seen in Figure 3.
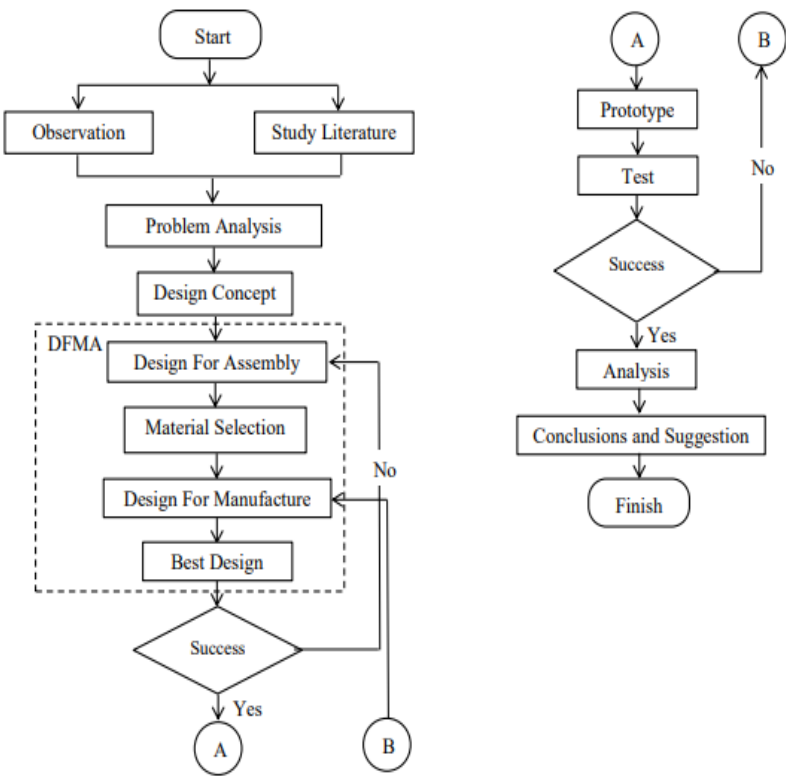

Figure 3: Research flowchart

\subsection{Design Concept}

This stage is the design concept which seeks a solution to the problem.At this stage, it explains the process that will be carried out to identify the solution from the late questionnaire results.

\subsection{Voice Of Custumer Collection Procedure}

To get the customer's wishes, in this study an open and closed questionnaire is needed, the following are the stages of implementing the questionnaire:

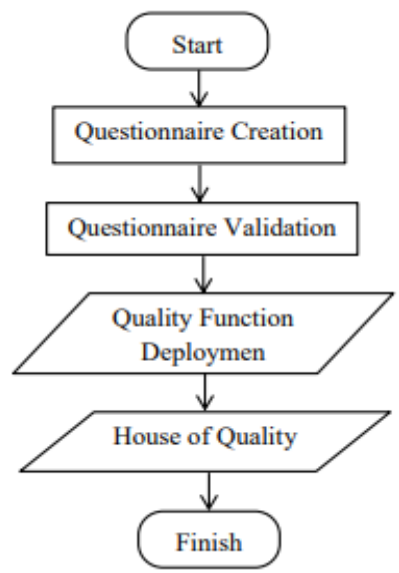

Figure 4: Stage of the design concept a. The questionnaires distribution and demographic data to the community in Batupanjang Village, Rupat Island.

b. Processing the most votes, selecting attributes from the most important to the least important.

c. The distribution of closed questionnaires and the selection of characteristic relationships with the voice of customer.

d. Processing master data to determine validation and reliability.

e. Making HOQ to determine target opportunities from the use of wastes as an alternative fuel for biomass stoves.

\subsection{Testing Procedure}

The testing procedures carried out are as follows:

- Prepare the biomass stove and a existing stove used.

- Prepare fuel, namely $2 \mathrm{~kg}$ of wood twigs for biomass stoves and existing stoves.

- Prepare 1 liter of water.

- Put the wood twigs into the biomass stove and existing stove as much as $1 \mathrm{~kg}$ each.

- Turn on the fire from the biomass stove and the existing stove.

- After the fire of the biomass stove and the existing stove are alive, boil 1 liter of water.

- Calculate the boiling time of water on the biomass stove and existing stove until the water boils.

- Next, after boiling the water, the amount of remaining fuel is calculated.

- Finally, a comparison can be made between the biomass stove and the stove.

\subsection{RESULT}

\subsection{Questionnaire Distribution}

In this study, the location for distributing questionnaires was in the village of Batu Panjang, Rupat Island, Riau Province. The number of respondents was 55 respondents. The validity test was carried out after obtaining data from the distribution of the questionnaire. Determination of the validity of the questionnaire data was done by using the Pearson Correlation. The community needs data is depicted in Table 1 .

Table 1: The community needs's data

\begin{tabular}{llccccc}
\hline \multirow{2}{*}{ No } & \multirow{2}{*}{ Aspect } & \multicolumn{4}{c}{ Value } & Total \\
\cline { 3 - 7 } & & $\mathrm{a}$ & $\mathrm{b}$ & $\mathrm{c}$ & $\mathrm{d}$ & \\
\hline 1 & Easy to get & 54 & 1 & 0 & 0 & 55 \\
2 & Easy to Operate & 49 & 6 & 0 & 0 & 55 \\
3 & Easy to fix & 48 & 7 & 0 & 0 & 55 \\
4 & Affordable prices & 47 & 8 & 0 & 0 & 55 \\
5 & Can be made by yourself & 43 & 12 & 0 & 0 & 55 \\
6 & Easy to move & 44 & 10 & 1 & 0 & 55 \\
\hline
\end{tabular}

$$
\begin{aligned}
& \text { Information: } \\
& \begin{array}{l}
a=\text { Very like } \\
b=\text { Like } \\
c=\text { Less like } \\
d=\text { Dislike }
\end{array}
\end{aligned}
$$

\subsection{Processing of House of Quality (HoQ)}

The results of testing the validity and reliability are entered into the house of quality matrix to obtain the attributes needed in the design of the Biomass Stove. This stage is the process of entering the data that has been obtained into the House of Quality. Then, it is analyzed to be applied properly. 
To build the HoQ in this research, data processing results from the collection of voice of customers were required by means of a survey written as an attribute of a product or service. These attributes are usually referred to as qualitative customer data and the numerical information of each attribute as quantitative data. The qualitative data are generally obtained from direct conversations and observations with consumers. The quantitative data is obtained from surveys or voting. This process is seek answers to the question of how consumer needs can be met. The translation is done through a brain storming process, namely by looking for ways that need to be done by the company to meet consumer needs. The questionnaire is filled with the level of importance between the relationship characteristics and the voice of the customer. The results of the questionnaire scores obtained a total of selection to determine the preferred target. In this study was defined the highest value of the relationship between characteristics and voice of customer. The processing of House of Quality (HoQ) can be seen in Table 2 and Table 3.

Table 2: Processing of House of Quality (HoQ)

\begin{tabular}{|c|c|c|c|c|c|c|}
\hline No & $\begin{array}{r}\text { Technical } \\
\text { Response }\end{array}$ & $\begin{array}{l}\frac{E}{50} \\
\frac{60}{0} \\
3\end{array}$ & $\frac{\frac{\mathrm{g}}{2}}{\frac{\mathrm{g}}{\mathrm{g}}}$ & 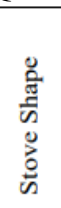 & $\begin{array}{l}\text { ते } \\
\overrightarrow{0} \\
\bar{n}\end{array}$ & 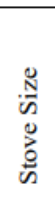 \\
\hline 1 & Easy to get & 4 & $\mathrm{O}$ & & & \\
\hline 2 & Easy to Operate & 5 & & $\bullet$ & $\bullet$ & 0 \\
\hline 3 & Easy to fix & 2 & $\mathrm{O}$ & $\bullet$ & & $\triangle$ \\
\hline 4 & Affordable prices & 6 & 0 & & & \\
\hline 5 & Can be made by yourself & 1 & & $\triangle$ & & \\
\hline 6 & Easy to move & 3 & & & 0 & $\bullet$ \\
\hline & Value Of Importance & & 72 & 64 & 54 & 44 \\
\hline
\end{tabular}

Table 3: Processing of House of Quality (HoQ), (continued)

\begin{tabular}{|c|c|c|}
\hline Rank & Information & Target Spesification \\
\hline \multirow{2}{*}{1} & \multirow{2}{*}{ Material type } & $\begin{array}{l}\text { 1. There are } 2 \text { types off material used, namely the same plate } \\
\text { and pipe using Mild Steel ST37. }\end{array}$ \\
\hline & & $\begin{array}{l}\text { 2. The material has a thickness of } 3 \mathrm{~mm} \text { because with that } \\
\text { thickness it is sufficient for the durability of the stove. }\end{array}$ \\
\hline \multirow{3}{*}{2} & \multirow{3}{*}{ Stove Shape } & $\begin{array}{l}\text { 1. This stove design is called Rocket Stove because it has a } \\
\text { rocket shape which consists of a fire funnel, a fuel funnel, } \\
\text { and a charcoal container. }\end{array}$ \\
\hline & & $\begin{array}{l}\text { 2. The size of the fire funnel and the fuel funnel are made } \\
\text { different, the size of the fuel funnel is bigger because } \\
\text { more fuel can enter. }\end{array}$ \\
\hline & & $\begin{array}{l}\text { 3. A place to accommodate ash as well as a place for air to } \\
\text { enter is made like a box because it is also the holder of the } \\
\text { stove. }\end{array}$ \\
\hline 3 & Savety & $\begin{array}{l}\text { 1. The stove is designed with good safety so as not to harm } \\
\text { the stove user. }\end{array}$ \\
\hline 4 & Stove Size & $\begin{array}{l}\text { 1. The stove is designed with a medium size where the stove } \\
\text { is easy to operate when operating in a sitting position with } \\
\text { a stove height of } 60 \mathrm{~cm} \text {. }\end{array}$ \\
\hline
\end{tabular}

Information :

\begin{tabular}{cll}
\hline Symbol & Score & Information \\
\hline Blank $>$ & 0 & No connection \\
$\triangle$ & 1 & Maybe there is a relationship \\
$\bigcirc$ & 3 & Medium relationship \\
$\bigcirc$ & 9 & Very strong relationship \\
\hline
\end{tabular}

\subsection{Biomass Stove Design}

The design of the biomass stove was based on the results of a questionnaire. The stove was designed with a simple shape, so that, it is easy to operate and easy to carry. The stove height was $60 \mathrm{~cm}$ and there were not many components on the stove. So, it is easy to use. The hoper for the fuel was designed bigger to look for an appropriate the fire funnel. Therefore, that more fuel can enter and more optimal in combustion. The combustion chamber was also made larger so that more air enters. Therefore, the resulting fire was more optimal.

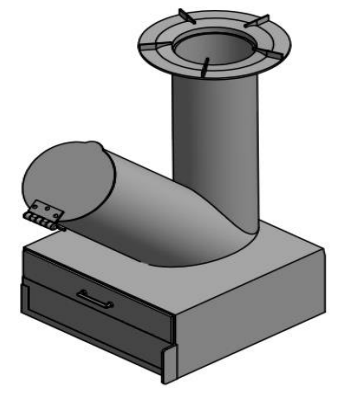

Figure 5: Alternative stove design 1

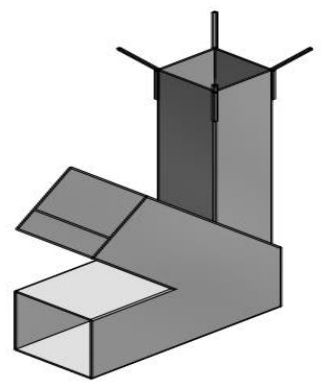

Figure 6: Alternative stove design 2

\subsection{Design Selection}

Based on the 2 designs (Figure 5 and 6 ), the best design was selected with the results from House of Quality (HoQ), which consists of several criteria, namely:

1. Material Type

The materials of the two designs have the same material, namely Mild Steel St 37 with a thickness of $3 \mathrm{~mm}$. For design 1, the fire funnel and fuel funnel were the round pipes, which the material was easy to get. The design 2, fire funnel and fuel funnel were square pipes, which were more difficult to manufacture.

2. Stove Shape

The design form of the two stoves was different. Design 1 has the shape of a fire funnel and fuel funnel in the form of a round pipe and an ash reservoir as well as a box-shaped incinerator. The size of fuel funnel pipe was larger so that the fuel entering large. The resulting fire was more optimal, in the combustion box. There was a combustion residue filter, which aims to keep the rest of the combustion of easy to dispose off. In the combustion box, there was a regulator of the size of the incoming air, which functions to increase and decrease the fire from the stove. Design 2 resulted in the funnel design on the stove in the form of a square pipe, which consists of a fire funnel, a fuel funnel, and a combustion exhaust funnel. The design 2 has the disadvantage that did not have a combustion filter and a regulator of the size off the fire from the stove. So in the shape of the stove, alternative design 1 is superior to alternative design 2 . 
3. Safety

Stove is designed with safety, which was not to endanger the user of the stove.

4. Stove Size

The two stove designs have different sizes, where alternative design 1 has a stove size with a height. So, that is easy to operate and a larger combustion box size as well as being a support for the stove. In alternative design 2, it has a different height, which lowers than design 1, higher in size. The size of the combustion chamber is also smaller than design 1. So from the size of the stove, alternative design 1 is superior to alternative design 2 .

From the design criteria's above, alternative design 1 was superior to alternative design 2 , which has advantages in the form of a stove shape and size.

\subsection{Test Result}

Stove testing was carried out aiming to see how optimal the stove fire and the resistance of the stove. The test was carried out by conducting an experiment by boiling 1 liter of water with a fuel capacity of $1 \mathrm{~kg}$. The test was compared with an existing stove, where the water and fuel capacities were the same. In addition, the biomass stove was also compared to a gas stove with the same boiled water capacity. From the comparison was sought the time of boiling water for each stove. In Table 4 can be seen the comparison of data for each of these stoves. Then, it can compare the time between a biomass stove with an existing stove and a biomass stove with a gas stove.

The first comparison was done to test between the biomass stove and the existing stove that used the same amount of dry wood twigs as fuel, which was $1 \mathrm{Kg}$. The biomass stove consumes $0.7 \mathrm{~kg}$ of wood twigs and the stove consumes $0.9 \mathrm{Kg}$ of wood twigs, which results in more boiling time for water from the biomass stove faster than the stove. The biomass stove has a boiling time of water to boil for 6 minutes 13 seconds and the time of the stove was 8 minutes 10 seconds. The difference between the boiling times of water from the stove was 2 minutes 7 seconds.

The second comparison was done to test between a biomass stove and a gas stove, which uses $3 \mathrm{~kg}$ of gas with an initial pressure of $75 \mathrm{psi}$ and a final pressure of $72 \mathrm{psi}$. The result test revealed a faster boiling time of water on a gas stove than a gas stove, which the difference in time from boiling water of 2 minutes 48 seconds. The time difference was quite short, was comparing to the time difference from the stove test.

Table 4: Comparative data on stove tests

\begin{tabular}{|c|c|c|c|c|c|c|}
\hline No & $\begin{array}{l}\text { Type of } \\
\text { Stove }\end{array}$ & Object & $\begin{array}{c}\text { Initial } \\
\text { Fuel } \\
\text { Capacity }\end{array}$ & $\begin{array}{l}\text { Remaining } \\
\text { Fuel }\end{array}$ & $\begin{array}{l}\text { Amount } \\
\text { Used }\end{array}$ & Times \\
\hline 1 & $\begin{array}{l}\text { Biomass } \\
\text { Stove }\end{array}$ & $1 \mathrm{~L}$ & $\begin{array}{l}1 \mathrm{Kg} \\
\text { Twig }\end{array}$ & $0.3 \mathrm{Kg}$ & $0.7 \mathrm{Kg}$ & $\begin{array}{c}6 \\
\text { minutes } \\
13 \\
\text { seconds }\end{array}$ \\
\hline 2 & Furnace & $1 \mathrm{~L}$ & $\begin{array}{l}1 \mathrm{Kg} \\
\text { Twig }\end{array}$ & $0.1 \mathrm{Kg}$ & $0.9 \mathrm{Kg}$ & $\begin{array}{c}8 \\
\text { minutes } \\
20 \\
\text { seconds }\end{array}$ \\
\hline 3 & $\begin{array}{c}\text { Gas } \\
\text { Stove } \\
\text { (Gas } 3 \\
\mathrm{Kg})\end{array}$ & $1 \mathrm{~L}$ & 75 Psi & 72 Psi & 3 Psi & $\begin{array}{c}3 \\
\text { minutes } \\
25 \\
\text { seconds }\end{array}$ \\
\hline
\end{tabular}

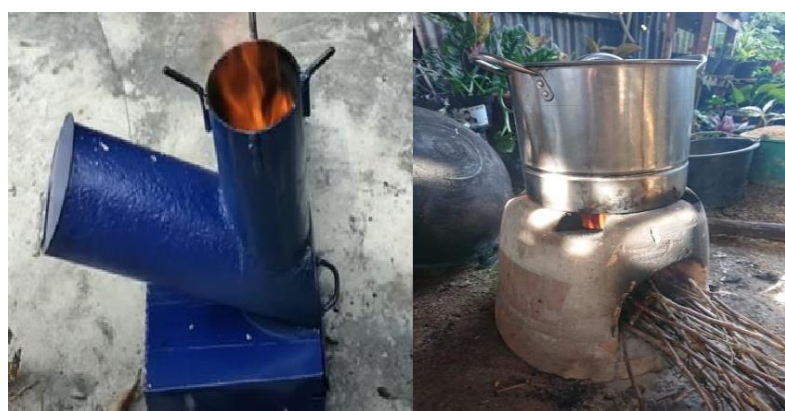

(a)

(b)

Figure 7: (a) Biomass stove test, (b) Furnace test

\subsection{CONCLUSION}

Based the HoQ data analyses, the optimal design alternative for biomass stoves is alternative design 1 . Because from these data results, alternative design 1 has an attractive design such as easy to operate and easy to obtain materials that match the results of the HoQ data. The test result for the biomass stove of the first biomass stove with a furnace. The test conducted to boil 1 liter of water with a fuel capacity of $1 \mathrm{~kg}$, on the biomass stove the fuel used of $0.7 \mathrm{~kg}$. The time generated from the biomass stove was 6 minutes 13 seconds. The furnace fuel was used $0.9 \mathrm{~kg}$ with a time of 8 minutes 20 seconds. It has a time difference of 2 minutes 47 seconds. The second comparison was done to test between a biomass stove and a gas stove. The result was revealed the time from the gas stove that was faster than the biomass stove with a time of 5 minutes 25 seconds and the time difference of 2 minutes 48 seconds.

\section{REFERENCES}

[1] Abdullah, K. 2002. Biomass energy potentials and utilization in Indonesia. Paper presented at ASEM Green IPP Network First Regional Workshop. Sofitel Silom. Bangkok (Thailand).

[2] Handoko, H., Adianto, A. \& Loon, S. (2020). The effect of population behavior on new renewable energy in primary energy mix for 2025 national target: Sumedang regency review, West Java, Journal of Ocean, Mechanical and Aerospace -Science and Engineering-, 64(1), 1-8.

[3] Panaka, P. (2006). Utilization of biomass sources in Indonesia: challenges \& opportunity for the Development. Presentation at Biomass Asia Forum, Tokyo.

[4] Wu, Y., Zhao, F., Liu, S. et al. (2018). Bioenergy production and environmental impacts, Geoscience Letter, 5, 14.

[5] Souza, G.M., Ballester, M.V.R., Cruz, C.H.B. et al (2017). The role of bio-energy in a climate-changing world, Environmental Development, 23, 57-64.

[6] Kuncoro, H. \& Damanik, L. (2005). Kompor Briket Batubara. Penebar Swadaya, Jakarta.

[7] Darmawan, Y. (2013). Inovasi teknologi tungku pembakaran dengan variasi ketinggian cerobong Fakultas Teknik Universitas Muhamadiyah Surakarta, Surakarta. 
(c) 2012 ISOMAse, All rights reserved

[8] Nasution, M.N. (2001). Manajemen Mutu Terpadu. Penerbit Ghalia Indonesia, Jakarta.

[9] Yohanes, Y. \& Rukmana, A. (2020). Potential investigation of b3 waste (used oil) of motorcycle as alternative diesel fuel, Journal of Ocean, Mechanical and Aerospace -Science and Engineering-, 64(2), 46-51.

[10] Cohen, L. (1995). Quality Function Deployment: How to Make QFD Work for You. Addison Wesley Publishing
Co. Erlangga.

[11] Yunus, N. \& Susilawati, A. (2020). Innovation of elbow fixture welding process based on Design for Manufacture and Assembly (DFMA). Journal of Ocean, Mechanical and Aerospace -Science and Engineering-, 64(1), 19-24.

[12] Boothroyd, G., Dewhurst, P. \& Knight, W. (2002). Product Design for Manufacture and Assembly, USA, Marcel Dekker, Inc. 